\title{
Molecular Characterization and Application of Random Amplified Polymorphic DNA Analysis of Mrakia and Sterigmatomyces Species
}

\author{
ROBERT MESSNER, ${ }^{1}$ HANSJÖRG PRILLINGER, ${ }^{1 *}$ FRIEDRICH ALTMANN,${ }^{2}$ KSENIJA LOPANDIC, \\ KATHARINA WIMMER, ${ }^{1}$ ORSOLYA MOLNÁR, ${ }^{1}$ AND FRANZ WEIGANG ${ }^{3}$ \\ Institut für Angewandte Mikrobiologie, Universität für Bodenkultur, A-1190 Vienna, ${ }^{1}$ Institut für Chemie, \\ Universität für Bodenkultur, A-1180 Vienna, ${ }^{2}$ and Analytische Messtechnik, \\ Hewlett-Packard GmbH, A-1222 Vienna, ${ }^{3}$ Austria
}

\begin{abstract}
The qualitative and quantitative monosaccharide spectra of purified yeast cell walls revealed that there are three phylogenetically distinct lineages of sterigma-forming basidiomycetous yeasts: (i) Kurtzmanomyces and Sterigmatomyces species, which contain high levels of mannose; (ii) Tilletiopsis species, which contain glucose, galactose, and small amounts of mannose; and (iii) Fellomyces, Kockovaella, Sterigmatosporidium, and Tsuchiyaea species, which appear to be closely related on the basis of their high levels of glucose and the presence of xylose. The yeast cell wall neutral sugars of Sporobolomyces antarcticus and Sterigmatomyces aphidis were similar to those of members of the genus Tilletiopsis. However, the possibility that these taxa are conspecific was eliminated by the results of a random amplified polymorphic DNA (RAPD) analysis. The conspecificity of Mrakia frigida and Mrakia nivalis, the conspecificity of Mrakia gelida and Mrakia stokesii, and the conspecificity of Sterigmatomyces halophilus and Sterigmatomyces indicus were confirmed by RAPD analysis results. RAPD analysis was found to be a simple and highly sensitive method which can be used to differentiate species at the DNA level; it can replace nuclear DNA-nuclear DNA hybridization experiments for species identification, characterization, and delimitation.
\end{abstract}

The genus Mrakia was proposed for Leucosporidium frigidum as a new genus of the Filobasidiaceae by Yamada and Komagata (51). The following four species that formerly had been placed in the genus Leucosporidium were transferred to the genus Mrakia: Mrakia frigida, Mrakia gelida, Mrakia nivalis, and Mrakia stokesii $(7,8,51)$. A homothallic, apomictic life cycle, self-sporulating simple holobasidia bearing terminal, sessile basidiospores, fermentation of sugars, the presence of ubiquinone Q-8, production of extracellular amyloid compounds, and yeast cell walls containing xylose are the most distinctive features of Mrakia species $(14,26,32,51)$. The fact that the genus Mrakia should be separated from phragmobasidial, smut-like Leucosporidium species (31) has been corroborated by the results of determinations of parts of the $18 \mathrm{~S}$ and 26S rRNA sequences $(6,9,48)$ and ultrastructural septal pore data (37).

The Mrakia species originally defined on the basis of their ability to ferment glucose and their ability to utilize nitrate or various carbon compounds (cellobiose, maltose, maltose, melibiose, raffinose) for growth $(7,8)$ turned out to be questionable taxa after investigations of the electrophoretic enzyme patterns $(39,52)$ and parts of the $18 \mathrm{~S}$ and $26 \mathrm{~S}$ rRNA sequences $(6,9,48)$. The electrophoretic enzyme patterns $(52)$ suggested that $M$. nivalis and $M$. stokesii are synonyms of $M$. frigida and $M$. gelida, respectively.

The genus Sterigmatomyces was introduced by Fell (5) for nonfilamentous, yeast-like fungi that are characterized by a unique method of cell division. The yeast cells produce one or more sterigmata, each of which gives rise to a single conidium. The conidium is disjointed at a septum in the middle of the sterigma. New conidia propagate in a similar way. In contrast

\footnotetext{
* Corresponding author. Fax: 43/1/3692924-400. Electronic mail address: iam@mail.boku.ac.at.
}

to Mrakia species, sexuality has not been reported in Sterigmatomyces species.

The mode of conidium separation, the ubiquinone system, and the presence or absence of xylose in yeast cell walls have been shown to be useful characteristics for defining different genera of sterigma-producing yeasts. Ubiquinone Q-9 was found in all Sterigmatomyces species whose conidia separate by cleavage of sterigmata at the midpoints $(40,46)$. On the basis of the presence of xylose in the cell walls the following two genera were proposed: Sterigmatomyces (xylose negative) and Tsuchiyaea (xylose positive) (49). Sterigmatomyces species that have conidia which separate at the distal ends of sterigmata and contain ubiquinone Q-10 have been transferred to the genera Fellomyces (xylose positive) and Kurtzmanomyces (xylose negative) $(47,49)$. Sterigmatosporidium polymorphum (17) is the only teleomorphic species that corresponds to an anamorphic Fellomyces (20) counterpart.

The proper generic assignment of another Sterigmatomyces species, Sterigmatomyces aphidis, remains a problem. There is considerable morphological similarity among Sterigmatomyces aphidis (15), Trichosporon oryzae (16), and Sporobolomyces antarcticus (11). Phenotypically, these three taxa are not like members of the genera Sterigmatomyces and Fellomyces. DNA comparisons (20) revealed that these three taxa are conspecific, although the reduced level of complementarity exhibited by Sterigmatomyces aphidis suggested that this organism is near the limit of relatedness exhibited by members of a species (21).

Species of the genera Mrakia and Sterigmatomyces are recognized as basidiomycetes because of the lamellar nature of their cell walls as determined by electron microscopy (18) and because of their positive color reactions with diazonium blue B (1). The distant phylogenetic relationship between these two genera $(12,13,30,32,48,50)$ and the availability of molecular information (e.g., nuclear DNA [nDNA]-nDNA reassociation data for Sterigmatomyces strains and electropherograms for Mrakia strains) make Mrakia and Sterigmatomyces species 
useful for evaluating the significance of random amplified polymorphic DNA (RAPD) analysis for species identification and the applicability of this technique for species delimitation. This rather simple and highly specific method, which was recently introduced independently by two group of workers $(43,45)$, is very useful for molecular identification of plantparasitic fungi (36).

On the basis of qualitative and quantitative yeast cell wall monosaccharide patterns and the ubiquinone isoprenologs, we tried to determine the proper genus for Sterigmatomyces aphidis.

\section{MATERIALS AND METHODS}

Yeast strains. The strains which we studied are listed in Table 1. All of these strains are maintained in the culture collection of the Institute of Applied Microbiology, Vienna, Austria.

Yeast cell wall analysis. Organisms were cultivated and yeast cell walls were purified as described by Prillinger et al. (33). To disintegrate yeast cells, we used a Vibrogen Cell Mill (Tübingen, Germany) and 0.5-mm-diameter glass beads (yeast pellet, distilled water, and glass beads, 1:1:3, wt/wt). The disintegration time used depended on the strain and was commonly between 20 and $30 \mathrm{~min}$ for a level of breakage of 90 to $95 \%$ (as determined by light microscopy). A 2-mg portion of powdered cell walls was suspended in $0.5 \mathrm{ml}$ of $2 \mathrm{M}$ trifluoroacetic acid, overlaid with gaseous nitrogen, and hydrolyzed for $4 \mathrm{~h}$ at $100^{\circ} \mathrm{C}$. The sediment was separated by centrifugation at 4,400 $\times g$ for $10 \mathrm{~min}$, and $5 \mu \mathrm{l}$ of the supernatant containing $2 \mu \mathrm{g}$ of myo-inositol (as an internal standard) was used for further investigation. The trifluoroacetic acid was removed by evaporation in a water bath at $35^{\circ} \mathrm{C}$ under a stream of gaseous nitrogen. After two additions of $200 \mu \mathrm{l}$ of methanol, the blow-off procedure was repeated.

Alditol acetates were prepared in two steps (35). During the first step the liberated monosaccharides were reduced by adding $70 \mu \mathrm{l}$ of $1 \mathrm{M}$ ammonia and $70 \mu \mathrm{l}$ of $4 \% \mathrm{NaBH}_{4}$. The reaction mixture was incubated overnight at room temperature. The remaining sodium borohydride was decomposed by two additions of $50 \mu \mathrm{l}$ of $2 \mathrm{M}$ acetic acid, two additions of 200 $\mu l$ of $1 \%$ acetic acid in methanol, and two additions of $200 \mu \mathrm{l}$ of pure methanol. Each addition was followed by evaporation to dryness under a stream of nitrogen. The second step, acetylation of the alditol derivatives, was performed as described by Dörfler (4), with minor modifications (we used 100 $\mu l$ of acetic acid anhydride instead of $400 \mu \mathrm{g}$; the preparation was incubated for $1 \mathrm{~h}$ at $100^{\circ} \mathrm{C}$ and was extracted; $500 \mu \mathrm{l}$ of dichloromethane was used to dissolve nitrogen-dried residues; and $1 \mathrm{ml}$ of distilled water was used for extraction). The dried residues were dissolved in $50 \mu \mathrm{l}$ of dichloromethane immediately before a gas-liquid chromatography-mass spectrometry analysis was performed, in which 0.5 to $2 \mu \mathrm{l}$ was used routinely.

Gas-liquid chromatography was carried out with an Erba Instruments model HRGC 5300 Mega Unit gas chromatograph equipped with a Finnigan MAT ion trap detector which was operated in the electron impact mode. Samples were injected (split, 1:5) into a type DB 225 capillary column $(30 \mathrm{~m}$ by $0.25 \mathrm{~mm}$; film thickness, $0.15 \mu \mathrm{m}$; J \& W Scientific). The oven temperature was programmed to increase from 160 to $200^{\circ} \mathrm{C}$ at a rate of $20^{\circ} \mathrm{C} / \mathrm{min}$ and then to $240^{\circ} \mathrm{C}$ at a rate of $3^{\circ} \mathrm{C} / \mathrm{min}$. Helium was used as the carrier gas at a pressure of 1.4 $\times 10^{5} \mathrm{~Pa}$. Ion masses between 41 and 240 were monitored. Parallel preparations were checked with a Hewlett-Packard model 5890 Series II gas chromatograph equipped with a hydrogen flame ionization detector and a type Rtx-2330 cap- illary column ( $60 \mathrm{~m}$ by $0.25 \mathrm{~mm}$; film thickness, $0.1 \mu \mathrm{m}$; Restek Corp. Bellefonte, Pa.). The oven temperature was programmed to increase from 160 to $200^{\circ} \mathrm{C}$ at a rate of $20^{\circ} \mathrm{C} / \mathrm{min}$ and then to $270^{\circ} \mathrm{C}$ at a rate of $3^{\circ} \mathrm{C} / \mathrm{min}$. Nitrogen was used as the carrier gas at a pressure of $1.6 \times 10^{5} \mathrm{~Pa}$.

Ubiquinone analysis. A ubiquinone analysis was performed by the Deutsche Sammlung von Mikroorganismen und Zellkulturen method of Tindall (38), with some modifications (we used $500 \mathrm{mg}$ of freeze-dried yeast cells grown in glucosepeptone-yeast extract medium to the early stationary phase; the preparation was stirred for 60 min in the dark with $4.5 \mathrm{ml}$ of hexane-methanol [1:2] and was extracted with $1.5 \mathrm{ml}$ of ice-cold hexane; and silica gel plates were developed in benzene). For the high-performance liquid chromatography (HPLC) analysis we used a Hewlett-Packard Series 1050 HPLC pump, a model 1050 diode array detector, and a model 1050 automatic sampler (Hewlett-Packard GmbH, Waldbronn, Germany). The column was a Hypersil $100 * 2.1 \mathrm{~mm}$ octyldecyl silane column. The solvent was HPLC grade acetonitrile (E. Merck). The standards used were Q-9 and Q-10 obtained from Sigma-Aldrich, Vienna, Austria. The instrument conditions were as follows: isocratic system at a flow rate of $0.4 \mathrm{ml} / \mathrm{min}$; oven temperature $70^{\circ} \mathrm{C}$; and injection volume, $2.5 \mu \mathrm{l}$. UV detection was at $275 \mathrm{~nm}$ (band width $2 \mathrm{~nm}$ ), and no reference wavelength was used. Spectra were determined for entire peaks to determine peak purity.

Denaturing protein electrophoresis. Samples were subjected to sodium dodecyl sulfate (SDS)-polyacrylamide gel electrophoresis (PAGE) as described by Laemmli (23) in a precast NOVEX gradient gel (8 to $16 \%$ acrylamide; Novel Experimental Technology, San Diego, Calif.) under the conditions described in the manufacturer's instructions. The molecular weight standard used was prestained SDS-PAGE standard-low range (Bio-Rad Laboratories, Richmond, Calif.). Protein samples were prepared by heating $5 \mathrm{mg}$ of lyophilized yeast cell wall powder (33) at $97^{\circ} \mathrm{C}$ for $10 \mathrm{~min}$ in SDS buffer $(100 \mu \mathrm{l}$ of $1 \mathrm{M}$ Tris- $\mathrm{HCl}$ buffer [pH 6.8]), $200 \mu \mathrm{l}$ of $100 \%$ glycerol, $200 \mu \mathrm{l}$ of $10 \% \mathrm{SDS}, 20 \mu \mathrm{l}$ of mercaptoethanol, $100 \mu \mathrm{l}$ of distilled water). Electropherograms were developed for $180 \mathrm{~min}$ by using settings of $125 \mathrm{~V}$ and $30 \mathrm{~mA}$.

DNA extraction. Chromosomal DNA was extracted rapidly by a modified hexadecyltrimethylammonium bromide method (24). A 50-mg portion of wet matter was harvested from solid medium and suspended in $0.4 \mathrm{ml}$ of hexadecyltrimethylammonium bromide buffer ( $2 \%$ [wt/vol] hexadecyltrimethylammonium bromide, $0.1 \mathrm{M}$ Tris- $\mathrm{HCl}[\mathrm{pH} 8.0], 1.2 \mathrm{M} \mathrm{NaCl}, 20 \mathrm{mM}$ EDTA, $5 \mathrm{mM}$ dithiothreitol) in a $1.5-\mathrm{ml}$ Eppendorf cup. The suspension was frozen at $-20^{\circ} \mathrm{C}$ and thawed three times and then incubated at $65^{\circ} \mathrm{C}$ for $30 \mathrm{~min}$. The suspension was vortexed for $1 \mathrm{~min}$ after $0.4 \mathrm{ml}$ of chloroform was added. The resulting mixture was centrifuged at $15,500 \times g$ for $20 \mathrm{~min}$, and $0.3 \mathrm{ml}$ of the clear upper phase was precipitated with $0.45 \mathrm{ml}$ of propane-2-ol. The precipitate formed during $30 \mathrm{~min}$ at $0^{\circ} \mathrm{C}$ was collected by centrifugation at $15,500 \times g$ for $15 \mathrm{~min}$, and the pellet was washed exhaustively with $1 \mathrm{ml}$ of $70 \%$ ( $\mathrm{vol} / \mathrm{vol}$ ) ethanol at room temperature. The pellet was dried under a vacuum and dissolved in $50 \mu \mathrm{l}$ of TE buffer. A $20-\mu \mathrm{l}$ portion of each preparation was checked for purity and RNA content, and concentrations were estimated by electrophoresis. Preparations chosen for RAPD analysis were diluted with TE buffer to a concentration of approximately $5 \mathrm{ng} / \mu \mathrm{l}$ compared with a control consisting of lambda DNA and were stored at $-20^{\circ} \mathrm{C}$.

RAPD analysis. A 3- $\mu$ l portion of a diluted DNA preparation containing 10 to 20 ng of DNA was subjected to RAPD amplification in $50 \mu \mathrm{l}$ (final aqueous volume) of a solution containing $10 \mathrm{mM} \mathrm{KCl}, 10 \mathrm{mM}\left(\mathrm{NH}_{4}\right)_{2} \mathrm{SO}_{4}, 20 \mathrm{mM}$ Tris $(\mathrm{pH}$ 
8.8), $4.5 \mathrm{mM} \mathrm{MgSO}_{4}, 0.1 \%$ (wt/vol) Triton X-100, each nucleotide triphosphate (Promega, Madison, Wis.) at a concentration of $0.2 \mathrm{mM}, 30 \mathrm{ng}$ of primer, $0.2 \mu \mathrm{g}$ of bovine serum albumin fraction $\mathrm{V}$ per $\mathrm{ml}$, and $0.8 \mathrm{U}$ of Taq DNA polymerase (homologous protein; supplied by Biomedica, Vienna, Austria). The mixture was overlaid with $50 \mu$ l of light mineral oil (Sigma Chemie GmbH, Diesenhofen, Germany) and processed with a Trio-Thermoblock TB1 thermocycler (Biometra, Göttingen, Germany). The analysis program used was as follows: denaturation at $98^{\circ} \mathrm{C}$ for $15 \mathrm{~s}$, annealing at $50^{\circ} \mathrm{C}$ for 60 $\mathrm{s}$, and extension at $72^{\circ} \mathrm{C}$ for $100 \mathrm{~s}$. A total of 40 cycles were used for 15-mer and 16-mer primers. For decamer primers annealing was performed at $32^{\circ} \mathrm{C}$ for $90 \mathrm{~s}$, and the number of cycles was reduced to 35 . Primers were synthesized by Codon Genetic Systems (Vienna, Austria) with a model 392 DNA synthesizer (Applied Biosystems, Foster City, Calif.). The reactions were stopped by adding EDTA to a concentration of $10 \mathrm{mM}$, and $20 \mu \mathrm{l}$ of each mixture was analyzed in a $1.3 \%$ (wt/vol) agarose gel in $0.5 \times \mathrm{TBE}$ buffer supplemented with 0.5 $\mu \mathrm{g}$ of ethidium bromide per $\mathrm{ml}$ at $4^{\circ} \mathrm{C}$ with electrophoresis at $5 \mathrm{~V} / \mathrm{cm}$. DNA fragments were visualized by transillumination and were photographed with a Polaroid system. The levels of similarity between individual lanes were calculated as described by Nei and Li (29).

PCR fingerprinting. Ribosomal DNA (rDNA) sequences were amplified either with primers ITS1 and ITS4 (44) (yielding both internal transcribed spacers and the 5.8S rDNA gene) or with primers GGTAGGAATACCCGCTG and GGCTTA ATCTCAGCAGATCG (yielding the entire 26S rDNA gene).

To amplify the 3-kb fragment containing the 26S rDNA, we used the proofreading, more thermostable VENT DNA polymerase (NEB, Beverly, Md.). The conditions used were the same as those used for the RAPD PCR (see above). A 20-ng portion of each primer and $0.5 \mathrm{U}$ of VENT DNA polymerase per vial were used. To avoid nonspecific products, the PCR program had to be altered according to the manufacturer's guidelines as follows: $98^{\circ} \mathrm{C}$ for $15 \mathrm{~s}, 60^{\circ} \mathrm{C}$ for $30 \mathrm{~s}$, and $72^{\circ} \mathrm{C}$ for $5 \mathrm{~min}$. A total of 35 cycles were used. The approximately $0.6-\mathrm{kb}$ fragment between primers ITS1 and ITS4 was amplified by using $2 \mathrm{U}$ of Taq DNA polymerase per vial, the $\mathrm{MgSO}_{4}$ concentration was reduced to $2 \mathrm{mM}$, and $10 \mathrm{ng}$ of each primer was included. The PCR program was as follows: $98^{\circ} \mathrm{C}$ for $15 \mathrm{~s}$, $55^{\circ} \mathrm{C}$ for $1 \mathrm{~min}$, and $72^{\circ} \mathrm{C}$ for $2 \mathrm{~min}$. A total of 40 cycles were used. A portion (10\%) of each PCR fragment was checked for amount and purity by standard agarose electrophoresis, and the rest was precipitated with 2 volumes of ethanol. The pellets were washed in $70 \%$ ethanol, dried, and digested with HinfI, Hae III, TaqI, $A l u \mathrm{I}$, or $M s p \mathrm{I}$. After digestion at $37^{\circ} \mathrm{C}$ overnight, the restriction fragments were subjected to agarose electrophoresis. The conditions used to separate the fragments from the $26 \mathrm{~S}$ rDNA were the same as those described above for the RAPD analysis. The fragments from the region of the internal transcribed spacers were separated with the same buffer system, except that $2 \%$ agarose (Seakem NuSieve GTG) was used.

\section{RESULTS AND DISCUSSION}

Tables 1 and 2 show the phylogenetic relationships of members of the genera of basidiomycetous yeasts which we investigated, based on the qualitative and quantitative monosaccharide patterns of purified yeast cell walls and some additional characteristics. The high levels of glucose and the presence of xylose in yeast cell wall hydrolysates of members of the genera Fellomyces, Mrakia, Kockovaella, Sterigmatosporidium, and Tsuchiyea suggested that these organisms are related to the tremelloid fungi (Tremella type) $(32,33)$. The presence of simple holobasidia (32), the ability to ferment carbohydrates (Table 1) (1), the presence of ubiquinone Q-8, and the presence of fucose in yeast cell walls (Table 2) (33) suggested that Mrakia species occupy a rather primitive and distinct position within the Tremella type; the results of partial sequence determinations of $18 \mathrm{~S}$ and $26 \mathrm{~S}$ rRNAs have corroborated this interpretation $(6,9,12,48,50)$.

Whereas the genera Fellomyces, Kockovaella, Sterigmatosporidium, and Tsuchiyea form a homogeneous cluster within the Tremella type (Table 2) $(9,28)$, Sterigmatomyces and Kurtzmanomyces species appear to be only distantly related to this group (53). On the basis of qualitative and quantitative cell wall neutral sugar data, the genera Kurtzmanomyces and Sterigmatomyces occupy a distinct position within the Microbotryum type (Table 2) $(31,33)$. An absence of fucose, which is often characteristic of representatives of the Microbotryum type indicates that there may be different phylogenetic lineages within this yeast type $(31,33)$. Although we were originally inclined to place Sterigmatomyces halophilus in the Ustilago type (30) on the basis of balanced amounts of glucose and mannose, the results obtained for another species in this study did not support this interpretation. The high levels of mannose in Sterigmatomyces elviae and both Kurtzmanomyces species are consistent with placement of these organisms in the Microbotryum type, which has been considered ancestral to the Ustilago and Tremella types $(30,33)$. The cell wall carbohydrate compositions of Mrakia species may indicate that there is an relationship between the Microbotryum and Tremella types, and the data for Sterigmatomyces halophilus and Sterigmatomyces indicus (Table 2) suggest that there is a similar relationship between the Microbotryum and Ustilago types.

The cell wall monosaccharides of Sterigmatomyces aphidis CBS $6821^{\mathrm{T}}$ ( $\mathrm{T}=$ type strain) and HB 54 and Sporobolomyces antarcticus CBS $5955^{\mathrm{T}}$ exhibit the characteristic Ustilago type pattern; namely, there are high levels of glucose and low levels of mannose, galactose is present, and no additional differentiating monosaccharides such as rhamnose, fucose, and xylose, are present (30). A positive diazonium blue B test (Table 1) eliminates the possibility that these organisms are related to ascomycetous yeasts and yeast stages containing galactose in their yeast cell walls (e.g., Schizosaccharomyces species) (33). In their quantitative glucose/mannose ratios and proportions of galactose, respectively, Sporobolomyces antarcticus and Sterigmatomyces aphidis strains resemble some Exobasidium species (e.g., Exobasidium symploci-japonicae) (30), Ustilago species (e.g., Ustilago grandis) (30), and Tilletiopsis species (30). The presence of ubiquinone Q-10 (Table 2) supports this interpretation. On the other hand, different Sporobolomyces species and Rhodotorula species exhibit a yeast cell wall monosaccharide pattern which is similar to the pattern exhibited by smut fungi of dicotyledons (31). The 5S rRNA sequence comparisons of Walker and Doolittle (42) and Blanz and Gottschalk (2) revealed a similar relationship. Both of these investigations placed Sporobolomyces antarcticus in a group that includes Tilletia controversa and Exobasidium vaccinii. The possibility that these organisms are phylogenetically related to the type species of the genus Vanrija, Vanrija humicola (Daszewska) Moore (25), can be eliminated. Vanrija (Cryptococcus) humicola contains significant levels of xylose in its cell walls (32). Partial large-subunit rRNA sequences $(9,12$, 54) revealed that $V$. humicola is distinct from Cryptococcus neoformans, the neotype species of the genus Cryptococcus. However, V. humicola cannot be excluded from the genus Trichosporon. Nakase et al. (26) rejected the genus Vanrija because it apparently includes various basidiomycetous ana- 
TABLE 1. Strains studied, their habitats, and selected characteristics that have phylogenetic importance (as determined by standard yeast characterization tests)

\begin{tabular}{|c|c|c|c|c|c|c|c|}
\hline \multirow[b]{2}{*}{ Species } & \multicolumn{2}{|c|}{ Strain $^{a}$} & \multirow[b]{2}{*}{ Habitat } & \multirow[b]{2}{*}{$\begin{array}{l}\text { Fermentation } \\
\text { of glucose }\end{array}$} & \multirow[b]{2}{*}{$\begin{array}{l}\text { Hydrolysis } \\
\text { by urease }\end{array}$} & \multirow[b]{2}{*}{$\begin{array}{l}\text { Formation } \\
\text { of } \mathrm{EAC}^{b}\end{array}$} & \multirow[b]{2}{*}{$\begin{array}{l}\text { Diazonium } \\
\text { blue B test }\end{array}$} \\
\hline & IAM no. & $\begin{array}{c}\text { Other } \\
\text { designation }\end{array}$ & & & & & \\
\hline $\begin{array}{l}\text { Kurtzmanomyces nectairei } \\
\text { (Rodrigues de Miranda) } \\
\text { Yamada et et al. (1988) }\end{array}$ & $\mathrm{HB} 106^{\mathrm{T}}$ & CBS $6405^{\mathrm{T}}$ & Cheese & - & + & - & + \\
\hline $\begin{array}{l}\text { Kurtzmanomyces tardus Giménez- } \\
\text { Jurado et van Uden }(1990)^{c}\end{array}$ & HB $268^{T}$ & CBS $7421^{\mathrm{T}}$ & Distilled water & - & + & - & + \\
\hline $\begin{array}{l}\text { Sterigmatomyces elviae Sonck et } \\
\quad \text { Yarrow (1969) }\end{array}$ & $\mathrm{HB} 104^{\mathrm{T}}$ & CBS $5922^{\mathrm{T}}$ & $\begin{array}{l}\text { Man with seborrheic eczema } \\
\text { (groin) }\end{array}$ & - & + & - & + \\
\hline $\begin{array}{l}\text { Sterigmatomyces halophilus Fell } \\
\text { (1966) }\end{array}$ & $\mathrm{HB} 100^{\mathrm{T}}$ & CBS $4609^{\mathrm{T}}$ & Air & - & + & - & + \\
\hline $\begin{array}{l}\text { Sterigmatomyces indicus (Fell) Fell } \\
\text { (1970) }\end{array}$ & $\mathrm{HB} 70^{\mathrm{T}}$ & CBS $5628^{\mathrm{T}}$ & Indian Ocean & - & + & - & + \\
\hline \multirow[t]{2}{*}{$\begin{array}{l}\text { Sterigmatomyces aphidis Henninger } \\
\text { et Windisch (1975) }\end{array}$} & HB 54 & & $\begin{array}{l}\text { Aphid secretion on leaves of } \\
\text { Solanum pseudocapsicum }\end{array}$ & - & + & - & + \\
\hline & $\mathrm{HB} 55^{\mathrm{T}}$ & CBS $6821^{\mathrm{T}}$ & & - & + & - & + \\
\hline $\begin{array}{l}\text { Sporobolomyces antarcticus Goto } \\
\text { et al. (1969) }\end{array}$ & $\mathrm{HB} 56^{\mathrm{T}}$ & CBS $5955^{\mathrm{T}}$ & Lake Vanda (sediment) & - & + & - & + \\
\hline \multirow{2}{*}{$\begin{array}{l}\text { Mrakia gelida (Fell et al.) Yamada } \\
\text { et Komagata (1987) }\end{array}$} & $\mathrm{HB} 76^{\mathrm{T}}$ & $\mathrm{JCM} 7858^{\mathrm{T}}$ & Antarctic soil & + & + & + & + \\
\hline & $\mathrm{HB} 101^{\mathrm{T}}$ & $\begin{array}{l}\text { DSM } \\
\quad 70882^{\mathrm{T}}\end{array}$ & & + & + & + & + \\
\hline $\begin{array}{l}\text { Mrakia stokesii (Fell et al.) } \\
\quad \text { Yamada et Komagata (1987) }\end{array}$ & HB $77^{\mathrm{T}}$ & CBS $5917^{\mathrm{T}}$ & Antarctic snow & + & + & + & + \\
\hline $\begin{array}{l}\text { Mrakia frigida (Fell et al.) } \\
\quad \text { Yamada et Komagata (1987) }\end{array}$ & HB $103^{T}$ & CBS $5270^{\mathrm{T}}$ & Antarctic soil & + & + & + & + \\
\hline $\begin{array}{l}\text { Mrakia nivalis (Fell et al.) } \\
\text { Yamada et Komagata (1987) }\end{array}$ & HB $102^{\mathrm{T}}$ & CBS $5266^{\mathrm{T}}$ & Antarctic soil & + & + & + & + \\
\hline \multirow[t]{2}{*}{$\begin{array}{l}\text { Fellomyces fuzhouensis (Yue) } \\
\text { Yamada et Banno (1988) }\end{array}$} & HB 94 & CBS 6133 & Mango flower & - & + & + & + \\
\hline & HB $95^{\mathrm{T}}$ & CBS $8243^{\mathrm{T}}$ & Mango flower & - & + & + & + \\
\hline \multirow{2}{*}{$\begin{array}{l}\text { Fellomyces penicillatus (Rodrigues } \\
\text { de Miranda) Yamada et Banno } \\
(1984)\end{array}$} & HB $98^{\mathrm{T}}$ & CBS $5492^{\mathrm{T}}$ & Contaminant on agar plate & - & + & + & + \\
\hline & HB $99^{T}$ & $\begin{array}{r}\text { CBS } 5492^{\mathrm{T}} \\
\text { (S-form) }\end{array}$ & & - & + & + & + \\
\hline \multirow[t]{2}{*}{$\begin{array}{l}\text { Fellomyces polyborus (Scott et van } \\
\text { der Walt) Yamada et Banno } \\
\text { (1984) }\end{array}$} & HB $96^{\mathrm{T}}$ & CBS $6072^{\mathrm{T}}$ & $\begin{array}{l}\text { Tunnels of Xyleborus torqua- } \\
\text { tus in Cussonia umbellifera } \\
\text { Ambregris }\end{array}$ & - & + & + & + \\
\hline & HB 97 & CBS 6643 & & - & + & + & + \\
\hline $\begin{array}{l}\text { Kockovaella imperatae Nakase et } \\
\text { al. (1991) }\end{array}$ & HB $58^{\mathrm{T}}$ & JCM $7826^{\mathrm{T}}$ & $\begin{array}{l}\text { On leaves of Imperata cylin- } \\
\text { drica }\end{array}$ & - & + & - & + \\
\hline $\begin{array}{l}\text { Kockovaella thailandica Nakase et } \\
\text { al. (1991) }\end{array}$ & $\mathrm{HB} 63^{\mathrm{T}}$ & $\mathrm{JCM} 7824^{\mathrm{T}}$ & $\begin{array}{l}\text { On leaves of Imperata cylin- } \\
\text { drica }\end{array}$ & - & + & - & + \\
\hline $\begin{array}{l}\text { Tsuchiyaea wingfieldii (van der } \\
\text { Walt et al.) Yamada et al. } \\
\text { (1988) }\end{array}$ & HB $93^{\mathrm{T}}$ & CBS $7118^{\mathrm{T}}$ & $\begin{array}{l}\text { Frass of a scolytid beetle on } \\
\text { olive plant (Olea europaea) }\end{array}$ & - & + & + & + \\
\hline \multirow[t]{2}{*}{$\begin{array}{l}\text { Sterigmatosporidium polymorphum } \\
\text { Kraepelin et Schulze (1982) }\end{array}$} & RBF 977 & CBS 8089 & Wet log in a mine & - & + & + & + \\
\hline & RBF 978 & CBS 8090 & Wet $\log$ in a mine & - & + & + & + \\
\hline
\end{tabular}

${ }^{a}$ Strains were obtained from the Centraalbureau voor Schimmelcultures (CBS), the DSM-Deutsche Sammlung von Mikroorganismen und Zellkulturen GmbH (DSM), the Japan Collection of Microorganisms (JCM), the Raiffeisen Bioforschung (RBF), and the collection of the Institute of Applied Microbiology in Vienna (IAM).

${ }^{b}$ EAC, extracellular, amyloid compounds (starch test).

${ }^{c}$ Reference 10.

morphic yeasts that supposedly have diverse phylogenetic origins.

The yeast cell wall monosaccharide compositions and the ubiquinone spectra which we determined suggest that Sporobolomyces antarcticus and Sterigmatomyces aphidis should be placed in the genus Tilletiopsis until the proper teleomorphic genus is found. Although ballistoconidia are not present in Sterigmatomyces aphidis, there can be no doubt that these two species are closely related. On the basis of DNA relatedness data Kurtzman (20) postulated that these organisms are conspecific. Our RAPD fingerprinting results support the view that these fungi are genetically distinct (Fig. 1 through 4), although they belong to the same genus. Using partial nucleotide sequencing, Nakase et al. (28) demonstrated convincingly that the mode of vegetative reproduction, such as production of ballistospores, stalked conidia, and budding yeast cells, does not reflect phylogenetic relationships among basidiomycetous yeasts and is a less significant taxonomic criterion than previ- 


\begin{tabular}{|c|c|c|c|c|c|c|c|}
\hline Species & stranl & D-Glucose & D-Mannose & D-Galactose & $\begin{array}{c}\text { DL- } \\
\text { Xylose }\end{array}$ & L-Fucose & . \\
\hline \multicolumn{8}{|l|}{ Microbotryum type } \\
\hline Kurtzmanomyces nectairei & HB $106^{\mathrm{T}}$ & 11 & 89 & $\operatorname{tr}^{c}$ & & & 10 \\
\hline Kurtzmanomyces tardus & HB $268^{\mathrm{T}}$ & 20 & 80 & $\operatorname{tr}$ & & & 10 \\
\hline Sterigmatomyces elviae & HB $104^{\mathrm{T}}$ & 19 & 80 & 1 & & & 9 \\
\hline Sterigmatomyces halophilus & $\mathrm{HB} 100^{\mathrm{T}}$ & 50 & 50 & $\operatorname{tr}$ & & & 9 \\
\hline Sterigmatomyces indicus & $\mathrm{HB} 70^{\mathrm{T}}$ & 49 & 48 & 2 & & & 9 \\
\hline \multicolumn{8}{|l|}{ Ustilago type } \\
\hline \multirow{2}{*}{ Sterigmatomyces aphidis } & $\mathrm{HB} 55^{\mathrm{T}}$ & 67 & 10 & 23 & & & 10 \\
\hline & HB54 & 62 & 9 & 29 & & & 10 \\
\hline Sporobolomyces antarcticus & HB $56^{\mathrm{T}}$ & 77 & 7 & 16 & & & 10 \\
\hline \multicolumn{8}{|l|}{ Tremella type } \\
\hline Mrakia gelida & $\mathrm{HB} 76^{\mathrm{T}}$ & 76 & 11 & 1 & 9 & 4 & 8 \\
\hline Mrakia stokesii & HB $77^{\mathrm{T}}$ & 89 & 5 & & 4 & 2 & 8 \\
\hline Mrakia frigida & $\mathrm{HB} 103^{\mathrm{T}}$ & 88 & 6 & & 4 & 2 & 8 \\
\hline Mrakia nivalis & HB $102^{\mathrm{T}}$ & 84 & 7 & & 6 & 2 & 8 \\
\hline \multirow{2}{*}{ Fellomyces fuzhouensis } & HB 94 & 81 & 9 & 1 & 9 & & 10 \\
\hline & HB $95^{\mathrm{T}}$ & 77 & 9 & & 14 & & 10 \\
\hline \multirow[t]{2}{*}{ Fellomyces penicillatus } & HB $98^{\mathrm{T}}$ & 79 & 11 & & 10 & & 10 \\
\hline & HB $99^{\mathrm{T}}$ & 80 & 11 & & 9 & & 10 \\
\hline \multirow[t]{2}{*}{ Fellomyces polyborus } & HB $96^{T}$ & 70 & 11 & & 19 & & 10 \\
\hline & HB 97 & 80 & 10 & & 10 & & 10 \\
\hline Kockovaella imperatae & HB $58^{\mathrm{T}}$ & 78 & 10 & & 12 & & 10 \\
\hline Kockovaella thailandica & $\mathrm{HB} 63^{\mathrm{T}}$ & 78 & 12 & & 10 & & 10 \\
\hline Tsuchiyaea wingfieldii & $\mathrm{HB} 93^{\mathrm{T}}$ & 83 & 8 & 1 & 8 & & 9 \\
\hline Sterigmatosporidium & RBF 977 & 76 & 14 & 2 & 8 & & 10 \\
\hline polymorphum & RBF 978 & 77 & 14 & 2 & 7 & & 10 \\
\hline
\end{tabular}

"None of the strains contained L-rhamnose.

${ }^{b}$ Data from references 46 and 50 and this study.

ctr, trace (less than 1\%).

ously believed. The qualitative and quantitative yeast cell wall monosaccharide data shown in Table 2 support the conclusions of Nakase et al. Stalked conidia, as well as ballistospores, are found in at least three phylogenetically distinct yeast types (the Microbotryum type, including Kurtzmanomyces, Sterigmatomyces, Sporobolomyces, and Sporidiobolus species [31]; the Ustilago type, including Ustilago and Tilletiopsis species [30]; and the Tremella type, including Fellomyces, Tsuchiyaea, Sterigmatosporidium, Kockovaella, and Bullera species [32, 33]).

Sterigmatomyces aphidis $\mathrm{HB} 54$ and $\mathrm{HB} 55^{\mathrm{T}}$, Sterigmatomyces elviae $\mathrm{HB} 104^{\mathrm{T}}$, Sterigmatomyces halophilus $\mathrm{HB} 100^{\mathrm{T}}$, Sterigmatomyces indicus $\mathrm{HB} 70^{\mathrm{T}}$, Sporobolomyces antarcticus $\mathrm{HB}$ $56^{\mathrm{T}}$, M. gelida $\mathrm{HB} 76^{\mathrm{T}}\left(=\mathrm{HB} 101^{\mathrm{T}}\right.$ ) (type strains obtained from the Deutsche Sammlung von Mikroorganismen und Zellkulturen and the Japan Collection of Microorganisms, respectively), $M$. frigida $\mathrm{HB} 103^{\mathrm{T}}$, M. stokesii $\mathrm{HB} 77^{\mathrm{T}}$, and $M$. nivalis $\mathrm{HB}$ $102^{\mathrm{T}}$, were assessed for species delimitation by performing a RAPD PCR analysis. Previously, this method has been useful for identifying and differentiating microorganisms $(34,36)$, and we were interested in comparing the resolving power of RAPD analysis with the resolving power of $\mathrm{nDNA}$ reassociation experiments (20) and with the resolving power of enzyme and protein electrophoresis $(39,52)$. The PCR fragment patterns generated by four different arbitrary primers were studied. The results obtained for the different Sterigmatomyces and Mrakia species illustrate the resolving power of the RAPD method (Fig. 1 through 4). When the distantly related Mrakia and Sterigmatomyces species were compared with each other, the background noise inherent in RAPD analysis became apparent.

Rapid DNA extraction without digestion or removal of
RNA yields the template for RAPD analysis, which is routinely used to determine the concentration of chromosomal DNA and the DNA-to-RNA ratio on the basis of the intensities of ethidium bromide-stained bands (Fig. 5). The presence of plasmid DNA in the preparations of two $M$. gelida type strains (Fig. 5, lanes 3 and 4) obtained from different culture collections was evident at five dominant positions at relative mobilities corresponding to fragment lengths of 5 to $0.5 \mathrm{~kb} M$. stokesii (lane 5) did not harbor any plasmid DNA, although conspecificity was proposed previously on the basis of the results of isoenzyme comparisons (52).

All Mrakia and Sterigmatomyces strains were processed simultaneously, and the PCR products were separated on agarose gels. Since the amplification reaction for RAPD analysis cannot be completely standardized, the absolute numbers and sizes of the fragments formed are by themselves not significant markers for strain differentiation. Therefore, all of the strains that are to be compared must be processed with one stock solution of premixed reagents in one run of the thermocycler used and loaded onto one gel for maximum information output.

Figures 1 through 4 show the results of RAPD analyses when we used primers M13 (GAGGGTGGCGGTTCT) and $\left(\mathrm{GACA}_{4}(24)\right.$ and primers ACGGTCTTGG (36) and TGC CGAGCTG (3). To calculate levels of DNA relatedness among species, bands were checked for reproducibility in parallel experiments. Fragments that had unique sizes (e.g., the fragment in Fig. 4, lane 10, indicated by an arrow) were not considered characteristics that represent differences, even though they were reproducible. While the procedure was kept the same during replicate analyses, very short or very long 


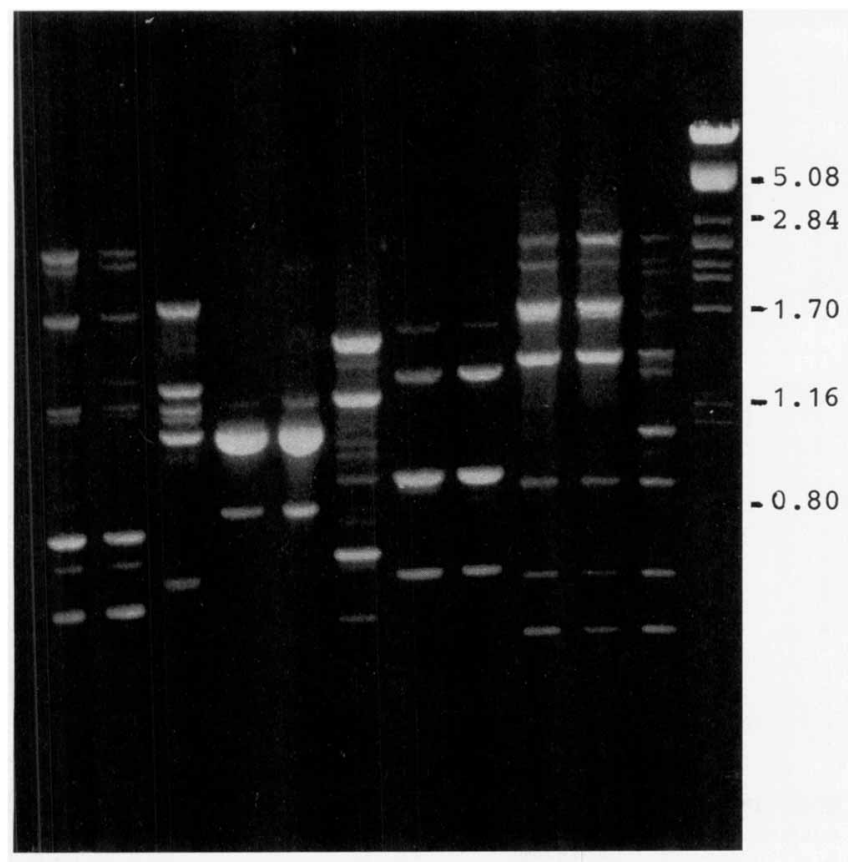

$$
\begin{array}{lllllllllllll}
1 & 2 & 3 & 4 & 5 & 6 & 7 & 8 & 9 & 10 & 11 & 12 & \mathrm{~KB}
\end{array}
$$

FIG. 1. RAPD patterns of Sterigmatomyces and Mrakia strains primed by M13 consensus sequence GAGGGTGGCGGTTCT. Lane 1, Sterigmatomyces aphidis HB 54; lane 2, Sterigmatomyces aphidis HB $55^{\mathrm{T}}$; lane 3, Sporobolomyces antarcticus HB $56^{\mathrm{T}}$; lane 4, Sterigmatomyces indicus $\mathrm{HB} 70^{\mathrm{T}}$; lane 5, Sterigmatomyces halophilus $\mathrm{HB} 100^{\mathrm{T}}$; lane 6 , Sterigmatomyces elviae $\mathrm{HB} 104^{\mathrm{T}}$; lane $7, M$. frigida $\mathrm{HB} 103^{\mathrm{T}}$; lane 8 , M. nivalis $\mathrm{HB} 102^{\mathrm{T}}$; lanes 9 and $10, M$. gelida $\mathrm{HB} 76^{\mathrm{T}}$ and $\mathrm{HB} 101^{\mathrm{T}}$, respectively; lane $11, M$. stokesii HB $77^{\mathrm{T}}$. Lane 12 contained lambda DNA digested with PstI. Note the similarity in the patterns of Sterigmatomyces halophilus and Sterigmatomyces indicus (lanes 4 and 5), $M$. frigida and $M$. nivalis (lanes 7 and 8 ), and $M$. gelida and $M$. stokesii (lanes 9 through 11).

fragments that resulted from minor variations in the reaction mixtures could be identified in individual experiments. Therefore, the $2-\mathrm{kb}$ fragment amplified from $M$. gelida $\mathrm{HB} 101^{\mathrm{T}}$ by TGCCGAGCTG may not distinguish this strain from $M$. stokesii $\mathrm{HB} 77^{\mathrm{T}}$ (Fig. 4). The total number of bands used for similarity calculations depended on the changes in new template-primer combinations. The number of fragments obtained

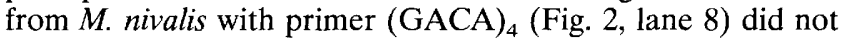
meet our expectations. In contrast to the other primers used, only a single band was observed reproducibly in this analysis. Reisolation of template DNA also did not result in any additional PCR products.

Levels of similarity were calculated individually for each primer, and the results were combined in equal proportions (Table 3 ). The level of background noise was determined from the similarity values obtained for different Mrakia and Sterigmatomyces species. The average range was about $14 \%$, and no range was greater than $19 \%$. The lowest similarity values which could be considered significant were obtained when we compared Sporobolomyces antarcticus $\mathrm{HB} 56^{\mathrm{T}}$ with Sterigmatomyces aphidis $\mathrm{HB} 54(28 \%)$ and $\mathrm{HB} 55^{\mathrm{T}}(33 \%)$. The values for all other pairs of strains belonging to different species in the Sterigmatomyces cluster (except Sterigmatomyces indicus) were at the level of background noise. The conspecificity of Sterigmatomyces halophilus $\mathrm{HB} 100^{\mathrm{T}}$ and Sterigmatomyces indicus HB $70^{\mathrm{T}}$, as shown previously by $\mathrm{nDNA}-\mathrm{nDNA}$ reassociation

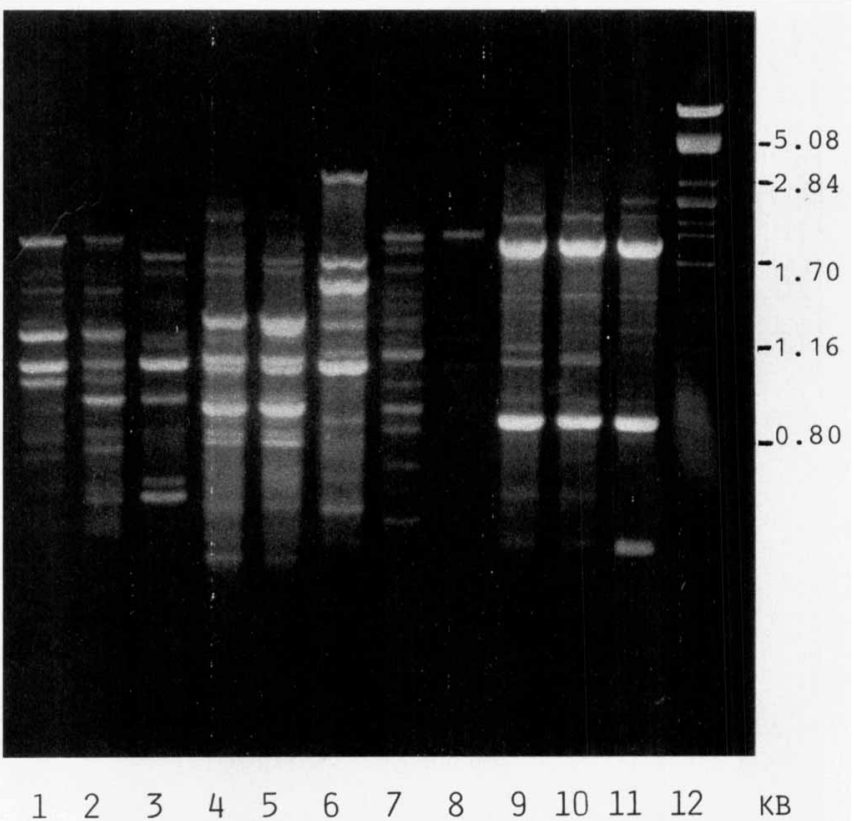

FIG. 2. RAPD patterns of Sterigmatomyces and Mrakia strains primed by $(\mathrm{GACA})_{4}$. For the contents of lanes 1 through 11 see the legend to Fig. 1. Compare the patterns in lanes 4 and 5, lanes 7 and 8 , and lanes 9 through 11 with the patterns shown in Fig. 1. Lane 12 contained lambda DNA digested with PstI.

(level of DNA complementarity, 98\%) (20), was confirmed by the results of the RAPD analysis performed in this study.

Kurtzman demonstrated that utilization of nitrate as a sole source of nitrogen, which has been used to separate Sterigmato-

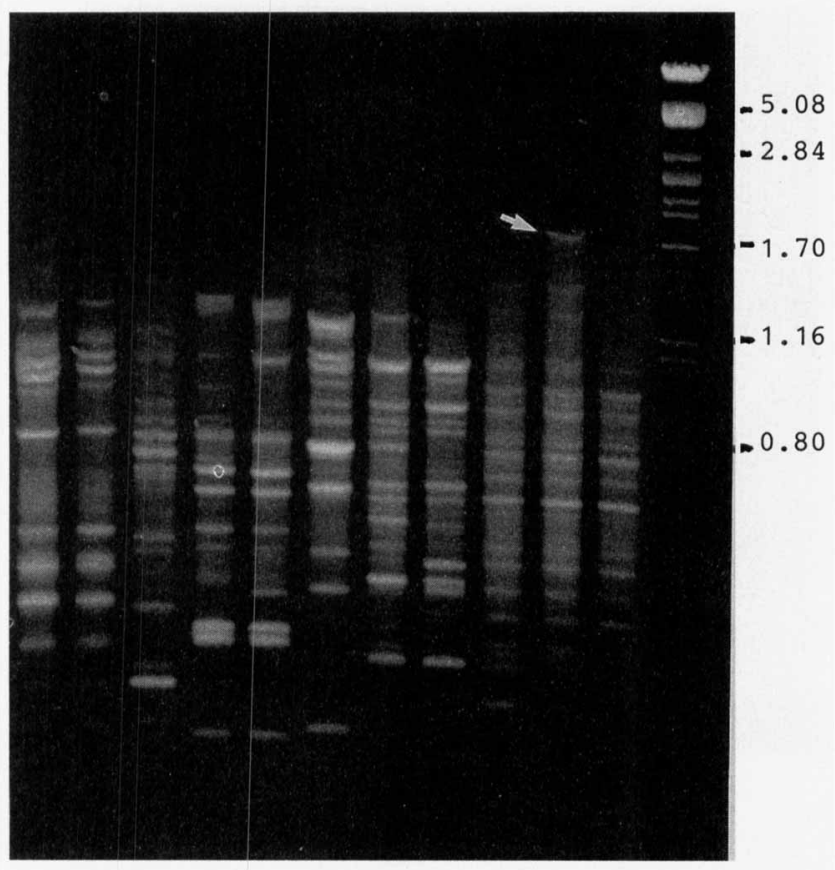

$\begin{array}{llllllllllllll}1 & 2 & 3 & 4 & 5 & 6 & 7 & 8 & 9 & 10 & 11 & 12 & \mathrm{~KB}\end{array}$

FIG. 3. RAPD patterns of Sterigmatomyces and Mrakia strains primed by ACGGTCTTGG. For the contents of lanes 1 through 11 see the legend to Fig. 1. Lane 12 contained lambda DNA digested with PstI. 


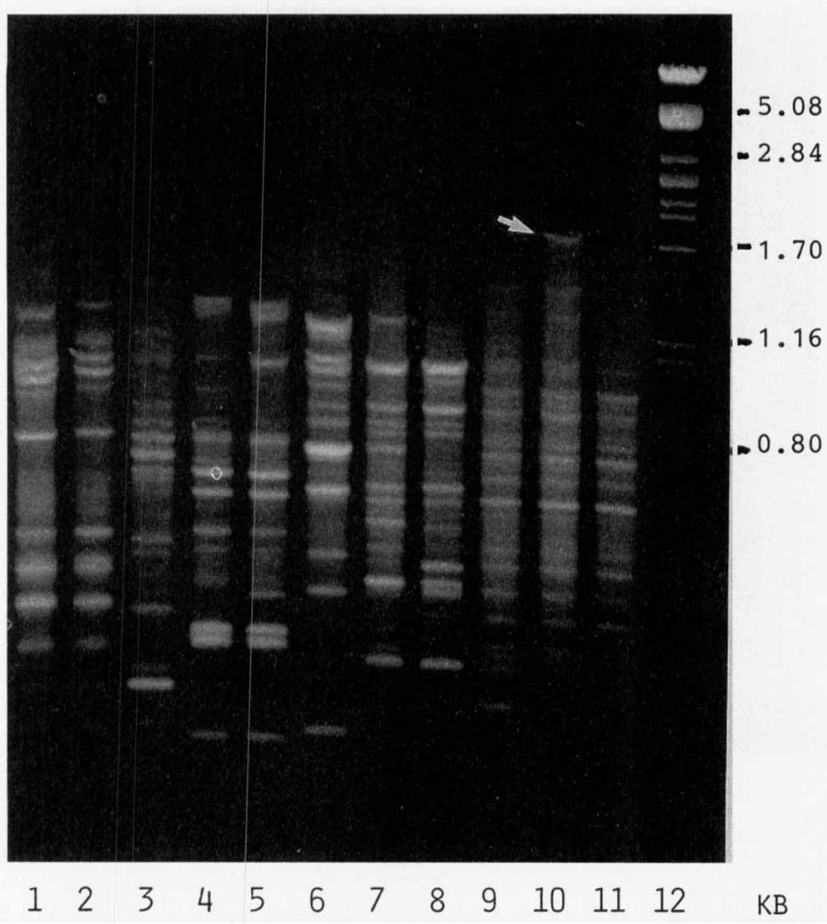

FIG. 4. RAPD patterns of Sterigmatomyces and Mrakia strains primed by TGCCGAGCTG. For the contents of lanes 1 through 11 see the legend to Fig. 1. Lane 12 contained lambda DNA digested with PstI. The arrow indicates a fragment that had a unique size and was not considered in strain comparisons (see text).

myces halophilus and Sterigmatomyces indicus, should not be considered a characteristic that has taxonomic importance (20). Figures 1 through 4 (lanes 4 and 5) show that the overall level of nDNA similarity, as indicated by a common DNA band pattern in RAPD analyses, is about $90 \%$ (Table 3 ). In contrast to the nDNA-nDNA reassociation value of $98 \%(20)$, we obtained greater resolution with the RAPD analysis, which can resolve close relationships with a good level of accuracy. Furthermore, a single RAPD comparison never results in a similarity value of more than $100 \%$, in contrast to the results obtained by reassociation methods (27). The visibility of the

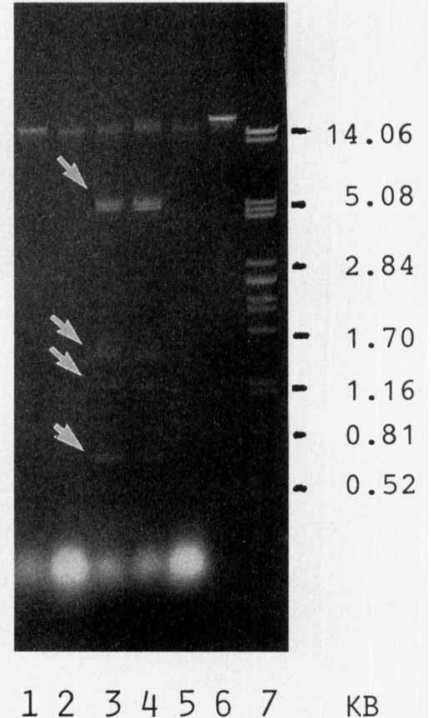

FIG. 5. Test for the quality and concentration of nDNA and the presence of plasmids in different Mrakia species. We performed agarose gel electrophoresis with extracted whole-cell DNAs from $M$. frigida $\mathrm{HB} 103^{\mathrm{T}}$ (lane 1), M. nivalis $\mathrm{HB} 102^{\mathrm{T}}$ (lane 2), M. gelida $\mathrm{HB} 76^{\mathrm{T}}$ (lane 3), M. gelida $\mathrm{HB} 101^{\mathrm{T}}$ (lane 4), and $M$. stokesii $\mathrm{HB} 77^{\mathrm{T}}$ (lane 5); $20 \mu \mathrm{l}$ of extract was used per lane. Lane 6 contained $50 \mathrm{ng}$ of lambda DNA, and lane 7 contained lambda DNA after digestion with PstI. Note the presence of a plasmid in $M$. gelida (arrows).

results compared further increases our confidence in the method.

Our results also show that the two strains of Sterigmatomyces aphidis studied, HB 54 and HB $55^{\mathrm{T}}$, are conspecific (level of similarity, 94\%) (Fig. 1 through 4, lanes 1 and 2) and that the type strains of $M$. gelida obtained from two different culture collections, strains $\mathrm{HB} 76^{\mathrm{T}}$ and HB $101^{\mathrm{T}}$, are conspecific (level of similarity, 100\%) (Fig. 1 through 4, lanes 9 and 10). Within the Mrakia cluster, the high levels of similarity between $M$. nivalis and $M$. frigida (70\%) (Fig. 1 through 4, lanes 7 and 8) and between $M$. gelida and $M$. stokesii (85\%) (Fig. 1 through 4, lanes 9 through 11) are striking. A classification based solely on the RAPD data supports the conclusions that $M$. stokesii and $M$. gelida are conspecific and that $M$. nivalis with $M$. frigida are

TABLE 3. Levels of similarity of the RAPD patterns, as determined with a $1.3 \%$ agarose gel

\begin{tabular}{|c|c|c|c|c|c|c|c|c|c|c|c|}
\hline \multirow[b]{2}{*}{ Strain } & \multicolumn{11}{|c|}{$\%$ Similarity with strain ${ }^{a}$ : } \\
\hline & $\begin{array}{l}\mathrm{HB} \\
54^{\mathrm{T}}\end{array}$ & $\begin{array}{c}\mathrm{HB} \\
55\end{array}$ & $\begin{array}{l}\text { HB } \\
56^{T}\end{array}$ & $\begin{array}{l}\text { HB } \\
70^{T}\end{array}$ & $\begin{array}{c}\mathrm{HB} \\
100^{\mathrm{T}}\end{array}$ & $\underset{104^{\mathrm{T}}}{\mathrm{HB}}$ & $\begin{array}{c}\mathrm{HB} \\
103^{\mathrm{T}}\end{array}$ & $\begin{array}{c}\mathrm{HB} \\
102^{\mathrm{T}}\end{array}$ & $\begin{array}{l}\text { HB } \\
76^{T}\end{array}$ & $\begin{array}{c}\text { HB } \\
101^{\mathrm{T}}\end{array}$ & $\begin{array}{l}\mathrm{HB} \\
77^{\mathrm{T}}\end{array}$ \\
\hline Sterigmatomyces aphidis HB 54 & 100 & 94 & 28 & 10 & 20 & 10 & 17 & 12 & $\mathrm{ND}^{b}$ & ND & ND \\
\hline Sterigmatomyces aphidis $\mathrm{HB} 55^{\mathrm{T}}$ & & 100 & 33 & 10 & 22 & 20 & 17 & 12 & ND & ND & ND \\
\hline Sporobolomyces antarcticus $\mathrm{HB} 56^{\mathrm{T}}$ & & & 100 & 20 & 20 & 16 & 6 & 2 & ND & ND & ND \\
\hline Sterigmatomyces indicus $\mathrm{HB} 70^{\mathrm{T}}$ & & & & 100 & 90 & 12 & 13 & 8 & 14 & 12 & 8 \\
\hline Sterigmatomyces halophilus $\mathrm{HB} 100^{\mathrm{T}}$ & & & & & 100 & 14 & 13 & 6 & 16 & 17 & 14 \\
\hline Sterigmatomyces elviae $\mathrm{HB} 104^{\mathrm{T}}$ & & & & & & 100 & 19 & 13 & 12 & 12 & 11 \\
\hline M. frigida $\mathrm{HB} 103^{\mathrm{T}}$ & & & & & & & 100 & 70 & 12 & 12 & 5 \\
\hline M. nivalis $\mathrm{HB} 102^{\mathrm{T}}$ & & & & & & & & 100 & 14 & 14 & 10 \\
\hline M. gelida $\mathrm{HB} 76^{\mathrm{T}}$ & & & & & & & & & 100 & 100 & 85 \\
\hline M. gelida $\mathrm{HB} 101^{\mathrm{T}}$ & & & & & & & & & & 100 & 85 \\
\hline M. stokesii $\mathrm{HB} 77^{\mathrm{T}}$ & & & & & & & & & & & 100 \\
\hline
\end{tabular}

${ }^{a}$ Levels of similarity were calculated by the method of Nei and $\mathrm{Li}(29)$

${ }^{b} \mathrm{ND}$, not determined. 


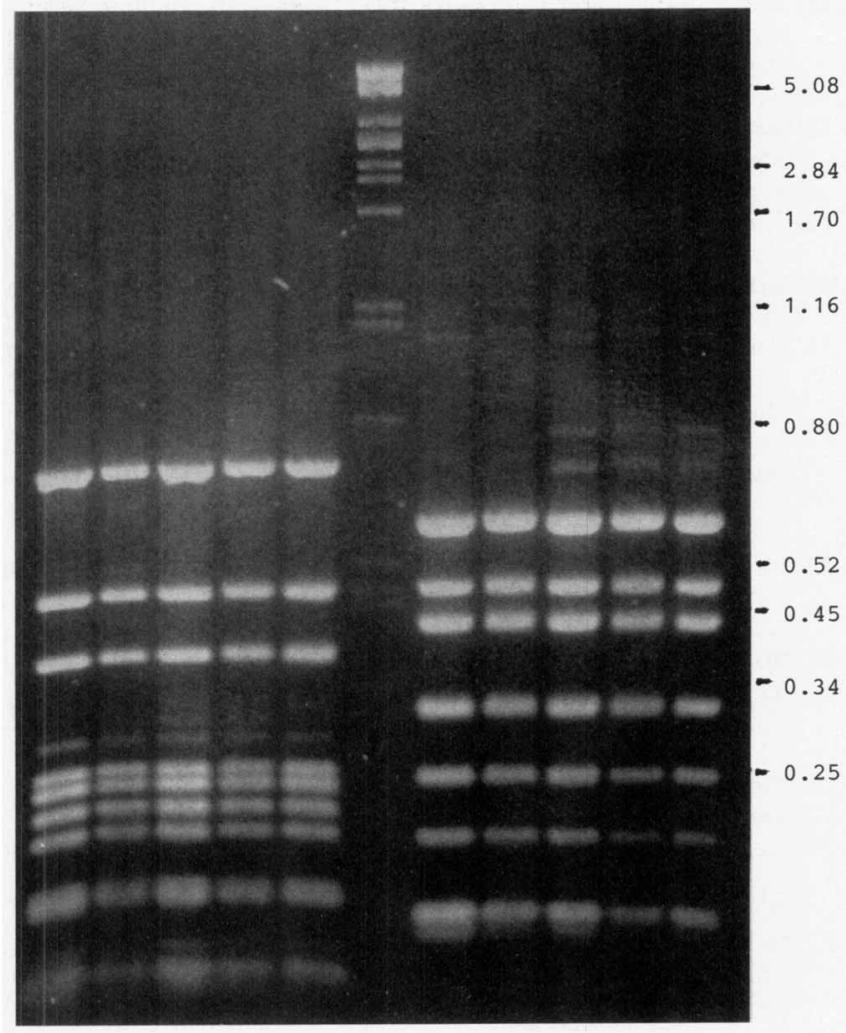

FIG. 6. PCR fingerprinting of whole 26S rDNAs amplified from the nDNAs of Mrakia species. Lanes 1 through 5, DNAs digested with Hinfl; lanes 7 through 11, DNAs digested with HaeIII; lane 6, lambda DNA digested with Pst I. Lanes 1 and 7, $M$. frigida; lanes 2 and 8, $M$. nivalis; lanes 3, 4, 9, and 10, M. gelida; lanes 5 and 11 , and $M$. stokesii.

conspecific because the levels of similarity (70 and $85 \%$ ) are consistent with the levels of variability observed within a single species. A global investigation of the genus Trichoderma by RAPD analysis resulted in levels of similarity in this range for the strains of one species which were isolated in one geographical area (19). An antarctic habitat and low cultivation temperatures $\left(15^{\circ} \mathrm{C}\right)$ are common to all Mrakia species (7).

A fifth primer, (GTG) ${ }_{5}$, yielded results that were partially consistent with the results obtained with the primers used in the experiments shown in Fig. 1 through 4 (data not shown). Heavy development of the background smear and the smaller average size of the fragments formed made it possible to identify only a few bands for similarity calculations. The huge number of small bands generated were not sufficiently resolved by electrophoresis. Therefore, the data obtained with this primer were not included in Table 3.

Our RAPD analysis data corroborate the data obtained from an electrophoretic comparison of enzymes performed by Yamada and Matsumoto (52). On the basis of identical electrophoretic mobilities of glucose-6-phosphate dehydrogenase, malate dehydrogenase, and fumarase in $M$. frigida and $M$. nivalis and in $M$. gelida and $M$. stokesii, only $M$. frigida and $M$. gelida were placed in the genus Mrakia. Because the descriptions of $M$. frigida and $M$. gelida were published before the descriptions of $M$. nivalis and $M$. stokesii $(7,51), M$. nivalis and $M$. stokesii are synonyms of $M$. frigida and $M$. gelida, respectively.

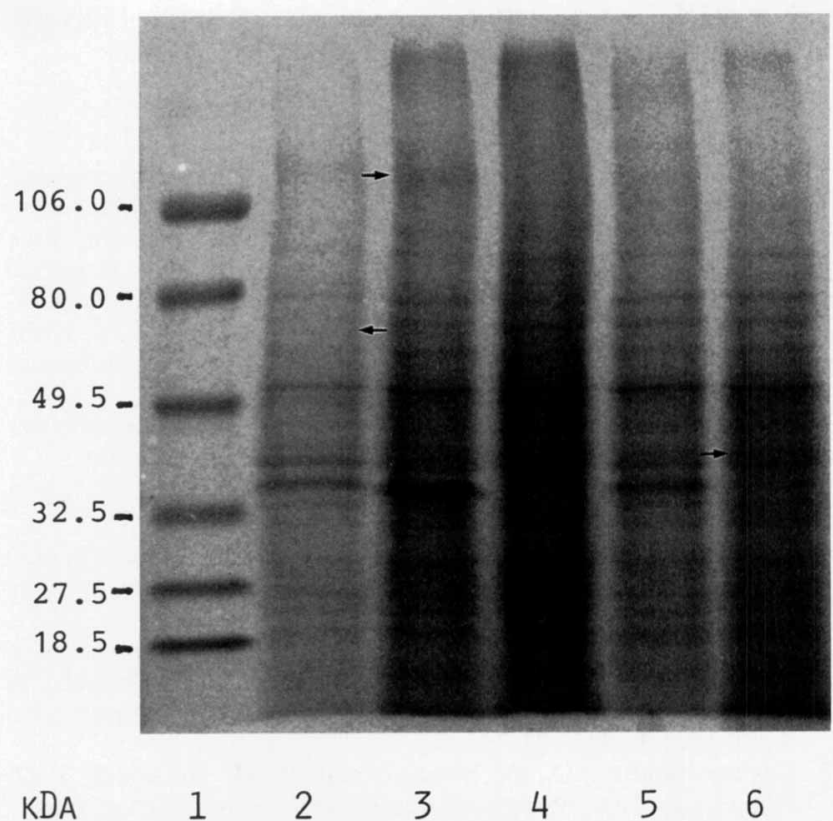

FIG. 7. SDS-PAGE of the cell wall proteins of four Mrakia species. Lane 2, $M$. frigida $\mathrm{HB} 103^{\mathrm{T}}$; lane $3, M$. nivalis $\mathrm{HB} 102^{\mathrm{T}}$; lanes 4 and 6 , M. gelida $\mathrm{HB} 101^{\mathrm{T}}$; lane $5, M$. stokesii $\mathrm{HB} 77^{\mathrm{T}}$. Protein bands which differentiate $M$. frigida and $M$. nivalis from $M$. gelida and $M$. stokesii are indicated by arrows (see text).

A comparison of the results of the RAPD PCR method with the results of rDNA restriction fragment analysis ("PCR fingerprinting") (Fig. 6) $(22,41)$ and electropherograms of yeast cell wall proteins (Fig. 7) (4), two methods previously used for species identification in our laboratory, revealed that RAPD analysis is superior to the other two methods. The PCR fingerprinting analysis revealed no differences among the four Mrakia species. When amplified 26S rDNA from a Mrakia species was digested with HinfI and HaeIII, we obtained 10 and 8 fragments, respectively (Fig. 6). The more variable region, which included both internal transcribed spacers, also did not reveal any differences among the Mrakia species, although five different enzymes were used. Digestion with HinfI, HaeIII, $T a q \mathrm{I}, A l u \mathrm{I}$, and $M s p \mathrm{I}$ resulted in three, four, four, three, and three fragments, respectively (data not shown). These results contrast with the results obtained by the RAPD analyses, which completely differentiated all species except the $M$. frigida-M. nivalis and $M$. stokesii-M. gelida pairs.

Although analysis of yeast cell wall proteins was superior to whole-cell protein electrophoresis for the identification of Taphrina and Exobasidium species (4), this method often has the disadvantage that interpretation and assignment of thin or weak bands in a high-band-density background are ambiguous (Fig. 7). In Fig. 7 we indicate bands which may further differentiate the $M$. frigida- $M$. nivalis and $M$. gelida-M. stokesii pairs. However, these differences are less convincing compared with the results obtained in the RAPD analysis.

In conclusion, we tried to show that morphological characteristics have to be checked very carefully for their usefulness for generic assignment. Stalked conidia occur in members of at least four different genera of basidiomycetes that are not closely related (the genera Fellomyces, Kurtzmanomyces, Sterigmatomyces, and Tilletiopsis). In addition, RAPD analysis is a new, simple, and highly sensitive method which differentiates organisms at the nDNA level. This method may replace 
nDNA-nDNA hybridization experiments for species identification, characterization, and delimitation.

\section{ACKNOWLEDGMENTS}

For helpful suggestions and cooperation, for constructive criticism, or for sending strains and valuable literature we are indebted to Sabine Baumgartner, Gabriella Giménez-Jurado, Gunda Kraepelin, Elke Lieckfeldt, Isabel Spencer-Martins, Thomas Börner, Gottfried Himmler, Peter Hoffmann, Hermann Katinger, Christian P. Kubicek, Cletus P. Kurtzman, Leo März, H.-P. Molitoris, Takashi Nakase, Klaus Scheide, Uwe Sleytr, Ulf Stahl, Eduard Taufratzhofer, Johannes Wöstemeyer, and Hewlett Packard Ges. m.b.H. (Vienna).

This work was supported by grants from the Jubiläumsfonds der Österreichischen Nationalbank and FWF (project PO9255-Bio).

\section{REFERENCES}

1. Barnett, J. A., R. W. Payne, and D. Yarrow. 1990. Yeasts: characteristics and identification, 2nd ed. Cambridge University Press, Cambridge.

2. Blanz, P. A., and M. Gottschalk. 1986. Systematic position of Septobasidium, Graphiola and other basidiomycetes as deduced on the basis of their $5 S$ ribosomal RNA nucleotide sequences. Syst. Appl. Microbiol. 8:121-127.

3. Caetano-Anolles, G., B. Bassam, and P. M. Gresshoff. 1992. Primer-template interactions during DNA amplification fingerprinting with single arbitrary oligonucleotides Mol. Gen. Genet. 235:157-165.

4. Dörfler, C. 1990. Vergleichende Untersuchungen zum biochemischen Aufbau der Zellwand an Hefestadien von niederen und höheren Basidiomyceten. Bibl. Mycol. 129:1-164.

5. Fell, J. W. 1966. Sterigmatomyces, a new fungal genus from marine areas. Antonie van Leeuwenhoek J. Microbiol. Serol. 32:99-104.

6. Fell, J. W., and C. P. Kurtzman. 1990. Nucleotide sequence analysis of a variable region of the large subunit rRNA for identification of marine-occurring yeasts. Curr. Microbiol. 21:295-300.

7. Fell, J. W., A. C. Statzell, I. L. Hunter, and H. J. Phaff. 1969. Leucosporidium gen. $\mathrm{n}$., the heterobasidiomycetous stage of several yeasts of the genus Candida. Antonie van Leeuwenhoek J. Microbiol. Serol. 35:433-462.

8. Fell, J. W., and A. Statzell Tallman. 1984. Genus 1. Leicosporidium Fell, Statzell, Hunter et Phaff, p. 496-508. In N. J. W. Kreger-van Rij (ed.), The yeasts: a taxonomic study, 3rd ed. Elsevier Science Publishers, Amsterdam.

9. Fell, J. W., A. Statzell-Tallman, M. J. Lutz, and C. P. Kurtzman. 1992. Partial rRNA sequences in marine yeasts: a model for identification of marine eukaryotes. Mol. Mar. Biol. Biotechnol. 1:175-186.

10. Giménez-Jurado, G., T. Plácido, A. J. Cidadao, C. Cabeca-Silva, E. Fonseca, H. J. Roeijmans, G. W. Eijk, and N. van Uden. 1990. Kurtzmanomyces tardus sp. nov., a new anamorphic yeast species of basidiomycetous affinity. Antonie van Leeuwenhoek J. Microbiol. Serol. 58:129-135.

11. Goto, S., J. Sugiyama, and H. Iizuka. 1969. A taxonomic study of antarctic yeasts. Mycologia 61:748-774.

12. Guého, E., L. Improvisi, R. Christen, and G. S. de Hoog. 1993. Phylogenetic relationships of Cryptococcus neoformans and some related basidiomycetous yeasts determined from partial large subunit rRNA sequences. Antonie van Leeuwenhoek J. Microbiol. Serol. 63:175-189.

13. Guého, E., C. P. Kurtzman, and S. W. Peterson. 1990. Phylogenetic relationships among species of Sterigmatomyces and Fellomyces as determined from partial rRNA sequences. Int. J. Syst. Bacteriol. 40:60-65.

14. Hamamoto, M., J. Sugiyama, and K. Komagata. 1988. Transfer of Rhodosporidium infirmominiatum to the genus Cystofilobasidium as Cystofilobasidium infirmominiatum comb. nov. J. Gen. Appl. Microbiol. 34:271-278.

15. Henninger, W., and S. Windisch. 1975. A new yeast of Sterigmatomyces, $S$. aphidis sp. n. Arch. Microbiol. 105:49-50.

16. Ito, H., H. Iizuka, and T. Sato. 1974. A new radio-resistant yeast, Trichosporon oryzae nov. sp. isolated from rice. Agric. Biol. Chem. 38:1597-1602.
17. Kraepelin, G., and U. Schulze. 1982. Sterigmatosporidium gen. n., a new heterothallic basidiomycetous yeast, the perfect state of a new species of Sterigmatomyces Fell. Antonie van Leeuwenhoek J. Microbiol. Serol. 48:471-483.

18. Kreger-van Rij, N. J. W., and M. Veenhuis. 1971. A comparative study of the cell wall structure of basidiomycetous and related yeasts. J. Gen. Microbiol. 68:87-95.

19. Kubicek, C. P. (Technical University, Vienna, Austria). 1993. Personal communication.

20. Kurtzman, C. P. 1990 . DNA relatedness among species of Sterigmatomyces and Fellomyces. Int. J. Syst. Bacteriol. 40:56-59.

21. Kurtzman, C. P., and H. J. Phaff. 1987. Molecular taxonomy, p. 63-94. In A. H. Rose and J. S. Harrison (ed.), The yeasts, vol. 1. Biology of yeasts. Academic Press, Inc. (London), Ltd., London.

22. Laaser, G., E. Möller, K.-D. Jahnke, G. Bahnweg, H. Prillinger, and H. H. Prell. 1989. Ribosomal DNA restriction fragment analysis as a tool in separating physiologically similar basidiomycetous yeasts. Syst. Appl. Microbiol. 11:170-175.

23. Laemmli, U. K. 1970. Cleavage of structural proteins during the assembly of the head of bacteriophage T4. Nature (London) 227:680-685.

24. Meyer, W., A. Koch, C. Niemann, B. Beyermann, J. T. Epplen, and T. Börner. 1991. Differentiation of species and strains among filamentous fungi by DNA fingerprinting. Curr. Genet. 19:239-242.

25. Moore, R. T. 1987. Additions to the genus Vanrija. Bibl. Mycol. 108:167-173

26. Nakase, T., M. Hamamoto, and J. Sugiyama. 1991. Recent progress in the systematics of basidiomycetous yeasts. Jpn. J. Med. Mycol. 32(Suppl.):21-30.

27. Nakase, T., M. Itoh, A. Takematsu, K. Mikata, I. Banno, and Y. Yamada. 1991. Kockovaella, a new ballistospore-forming anamorphic yeast genus. J. Gen. Appl. Microbiol. 37:175-197.

28. Nakase, T., A. Takematsu, and Y. Yamada. 1993. Molecular approaches to the taxonomy of ballistosporous yeasts based on the analysis of the partial nucleotide sequences of $18 \mathrm{~S}$ ribosomal ribonucleic acids. J. Gen. Appl. Microbiol. 39:107-134.

29. Nei, M., and W.-H. Li. 1979. Mathematical model for studying genetic variation in terms of restriction endonucleases Proc. Natl. Acad. Sci. USA 76:5269-5273.

30. Prillinger, H., C. Dörfler, G. Laaser, and G. Hauska. 1990. Ein Beitrag zur Systematik und Entwicklungsbiologie höherer Pilze: Hefe-Typen der Basidiomyceten. Teil III: Ustilago-Typ. Z. Mykol. 56:251-278.

31. Prillinger, H., C. Dörfler, G. Laaser, and W. Lockau. 1991. Ein Beitrag zur Systematik und Entwicklungsbiologie höherer Pilze: Hefe-Typen der Basidiomyceten. Teil II: Microbotryum-Typ. Bot. Acta 104:5-17.

32. Prillinger, H., G. Laaser, C. Dörfler, and K. Ziegler. 1991. Ein Beitrag zur Systematik und Entwicklungsbiologie höherer Pilze: Hefe-Typen der Basidiomyceten. Teil IV: Dacrymyces-Typ, Tremella-Typ. Sydowia Ann. Mycol. 43:170-218.

33. Prillinger, H., F. Oberwinkler, C. Umile, K. Tlachac, R. Bauer, C. Dörfler, and E. Taufratzhofer. 1993. Analysis of cell wall carbohydrates (neutral sugars) from ascomycetous and basidiomycetous yeasts with and without derivatization. J. Gen. Appl. Microbiol. 39:1-34.

34. Ralph, D., M. McClelland, J. Welsh, G. Baranton, and P. Perolat. 1993. Leptospira species categorized by arbitrarily primed polymerase chain reaction (PCR) and by mapped restriction polymorphisms in PCR-amplified rRNA genes. J. Bacteriol. 175:973-981.

35. Säämänen, A.-M., and M. Tammi. 1988. A sensitive GLC-method for component sugars and O-glycosidic linkage monosaccharides of cartilage proteoglycans. Glycoconjugate 5:235-243.

36. Schäfer, C., and J. Wöstemeyer. 1992. Random primer dependent PCR differentiates aggressive from nonaggressive isolates of the oilseed rape pathogen Phoma lingam. J. Phytopathol. 136:124-136.

37. Suh, S.-O., A. Hirata, J. Sugiyama, and K. Komagata. 1993. Septal ultrastructure of basidiomycetous yeasts and their taxonomic implications with observations on the ultrastructure for Enythrobasidium hasegawianum and Sympodiomycopsis paphiopedili. Mycologia 85:30-37.

38. Tindall, B. J. Extraction and analysis of respiratory lipoquinones 
from microorganisms. DSM-Deutsche Sammlung von Mikroorganismen und Zellkulturen GmbH, Braunschweig, Germany.

39. Vancanneyt, M., E. Van Lerberge, J.F. Berny, G. L. Hennebert, and K. Kersters. 1992. The application of whole-cell protein electrophoresis for the classification and identification of basidiomycetous yeast species. Antonie van Leeuwenhoek J. Microbiol. Serol. 61:69-78.

40. van der Walt, J. P., Y. Yamada, N. W. Ferreira, and P. D. G. Richards. 1987. New basidiomycetous yeasts from Southern Africa. II. Sterigmatomyces wingfieldii sp. n. Antonie van Leeuwenhoek J. Microbiol. Serol. 53:137-142.

41. Vilgalys, R., and M. Hester. 1990. Rapid genetic identification and mapping of enzymatically amplified ribosomal DNA from several Cryptococcus species. J. Bacteriol. 172:4238-4246.

42. Walker, W. F., and W. F. Doolittle. 1983. 5S rRNA sequences from eight basidiomycetes and fungi imperfecti. Nucleic Acids Res. 11:7625-7630.

43. Welsh, J., and M. McClelland. 1990. Fingerprint genomes using PCR with arbitrary primers. Nucleic Acids Res. 18:7213-7218.

44. White, T. J., T. D. Bruns, S. Lee, and J. Taylor. 1990. Amplification and direct sequencing of fungal ribosomal genes for phylogenetics, p. 315-322. In M. A. Innis, D. H. Gelfand, J. J. Sininski, and T. J. White (ed.), PCR protocols. Academic Press, San Diego, Calif.

45. Williams, J. G. K., A. R. Kubelik, K. J. Livak, J. A. Rafalski, and S. V. Tingey. 1990. DNA-polymorphisms amplified by arbitrary primers are useful as genetic markers. Nucleic Acids Res. 18:65316535.

46. Yamada, Y., and I. Banno. 1984. The coenzyme Q system in strains of species in the genus Sterigmatomyces (Cryptococcaceae) and its teleomorphic genus Sterigmatosporidium. Trans. Mycol. Soc. Jpn. 25:455-460.

47. Yamada, Y., M. Itoh, H. Kawjasaki, I. Banno, and T. Nakase. 1988. Kurtzmanomyces gen. nov., an anamorphic yeast genus for the Q-10-equipped organism whose conidium is freed by an end-break in the sterigma which branches or elongates to produce additional conidia and whose cells contain no xylose. J. Gen. Appl. Microbiol. 34:503-506.
48. Yamada, Y., and H. Kawasaki. 1989. The molecular phylogeny of the Q-8-equipped basidiomycetous yeast genera Mrakia Yamada et Komagata and Cystofilobasidium Oberwinkler et Bandoni based on the partial sequences of $18 \mathrm{~S}$ and $26 \mathrm{~S}$ ribosomal ribonucleic acids. J. Gen. Appl. Microbiol. 35:173-183.

49. Yamada, Y., H. Kawasaki, M. Itoh, I. Banno, and T. Nakase. 1988. Tsuchiyaea gen. nov., an anamorphic yeast genus for the Q-9equipped organism whose reproduction is either by enteroblastic budding or by the formation of conidia which are disjointed at a septum in the mid-region of the sterigmata and whose cells contain xylose. J. Gen. Appl. Microbiol. 34:507-510.

50. Yamada, Y., H. Kawasaki, T. Nakase, and I. Banno. 1989. The phylogenetic relationship of the conidium-forming anamorphic yeast genera Sterigmatomyces, Kurtzmanomyces, Tsuchiyaea, and Fellomyces and the teleomorphic yeast genus Sterigmatosporidium on the basis of the partial sequences of $18 \mathrm{~S}$ and $26 \mathrm{~S}$ ribosomal ribonucleic acids. Agric. Biol. Chem. 53:2993-3001.

51. Yamada, Y., and K. Komagata. 1987. Mrakia gen. nov., a heterobasidiomycetous yeast genus for the Q-8-equipped, self-sporulating organisms which produce a unicellular metabasidium formerly classified in the genus Leucosporidium. J. Gen. Appl. Microbiol. 33:455-457.

52. Yamada, Y., and A. Matsumoto. 1988. An electrophoretic comparison of enzymes in strains of species in the genus Mrakia Yamada et Komagata (Filobasidiaceae). J. Gen. Appl. Microbiol. 34:201-208.

53. Yamada, Y., T. Nagahama, I. Banno, G. Giménez-Jurado, and N. van Uden. 1991. The phylogenetic relationship of Kurtzmanomyces tardus Giménez-Jurado et van Uden (Cryptococcaceae) based on the partial sequences of $18 \mathrm{~S}$ and $26 \mathrm{~S}$ ribosomal RNA's. J. Gen. Appl. Microbiol. 37:321-324.

54. Yamada, Y., T. Nagahama, H. Kawasaki, and I. Banno. 1990. The phylogenetic relationship of the genera Phaffia Miller, Yoneyama et Soneda and Cryptococcus Kützing emend. Phaff et Spencer (Cryptococcaceae) based on the partial sequences of $18 \mathrm{~S}$ and $26 \mathrm{~S}$ ribosomal ribonucleic acids. J. Gen. Appl. Microbiol. 36:403-414. 